\title{
Effect of Exogenous Oxytocin on Contractility of the Female Reproductive Tract of the Rabbit
}

\author{
Yoshio Tsutsumi and Hiroyuki Suzuki \\ Department of Animal Science, Faculty of Agriculture, \\ Hokkaido University, Sapporo-shi 060
}

(Received May 8, 1981)

\begin{abstract}
The effect of oxytacin on the contractility of oviductal isthmus, uterus and cervix was investigated in rabbits before and after mating. The oviductal responsiveness to oxytocin was conspicuous during estrus and up to 3-4 days after mating, followed by its gradual decrease; but an abrupt decline was evident in 2 of 5 does on Day 7 . Uterine motility was affected by oxytocin until 2 days after mating, and the uterine sensitivity decreased thereafter. Cervical responses to oxytocin were not consistent during estrus and were not noted 3 days after mating.
\end{abstract}

Jpn. J. Zootech. Sci., 52 (12): 898-902, 1981

Oxytocin has been generally accepted as a stimulator of uterine muscular activity in several species, both in vitro and in vivo. It has been believed that effects of oxytocin are affected by ovarian hormones. In rabbits, estrogen increases the responsiveness to oxytocin, while progesterone decreases $\mathrm{it}^{\mathrm{t}^{-5}}$. . However, very little is known of the effects of this drug on the oviductal and cervical motility of rabbits during early pregnancy. The purpose of the present investigation is to study the effects of exogenous oxytocin on the contractile activities of the reproductive organs of rabbits before and after mating.

\section{Materials and Methods}

Five adult, female Japanese White rabbits were used. Muscular activities of the reproductive organs were recorded in vivo by placing polyurethane balloon catheters into the lumina of the oviductal isthmus, uterus and cervix on the ipsilateral side, as reported previously ${ }^{6}$. Following recovery from the surgery for fitting the catheters, intraluminal pressure changes of each organ were simultaneously monitored daily for about $60 \mathrm{~min}$ by a multipurpose polygraph (RM-85, Nihon Kohden, Japan) using preamplifiers (RPF-5, Nihon Kohden) and Ailtech pressure transducers (MS-20S, U.S.A.). All animals received intravenous injections of 5 IU of oxytocin (Showa Yakuhin-kako, Japan) one or more days prior to mating, and once each day for 7 days after mating. Human chorionic gonadotrophin (50 IU, Gonatropin, TeikokuZöki, Japan) was given intravenously just after mating. Recordings of contractile motilities of three different organs were always started at least 30 min before the oxytocin administration. The day of mating was designated as Day 0 . 
Oxytocin and Contractility of Reproductive Tract

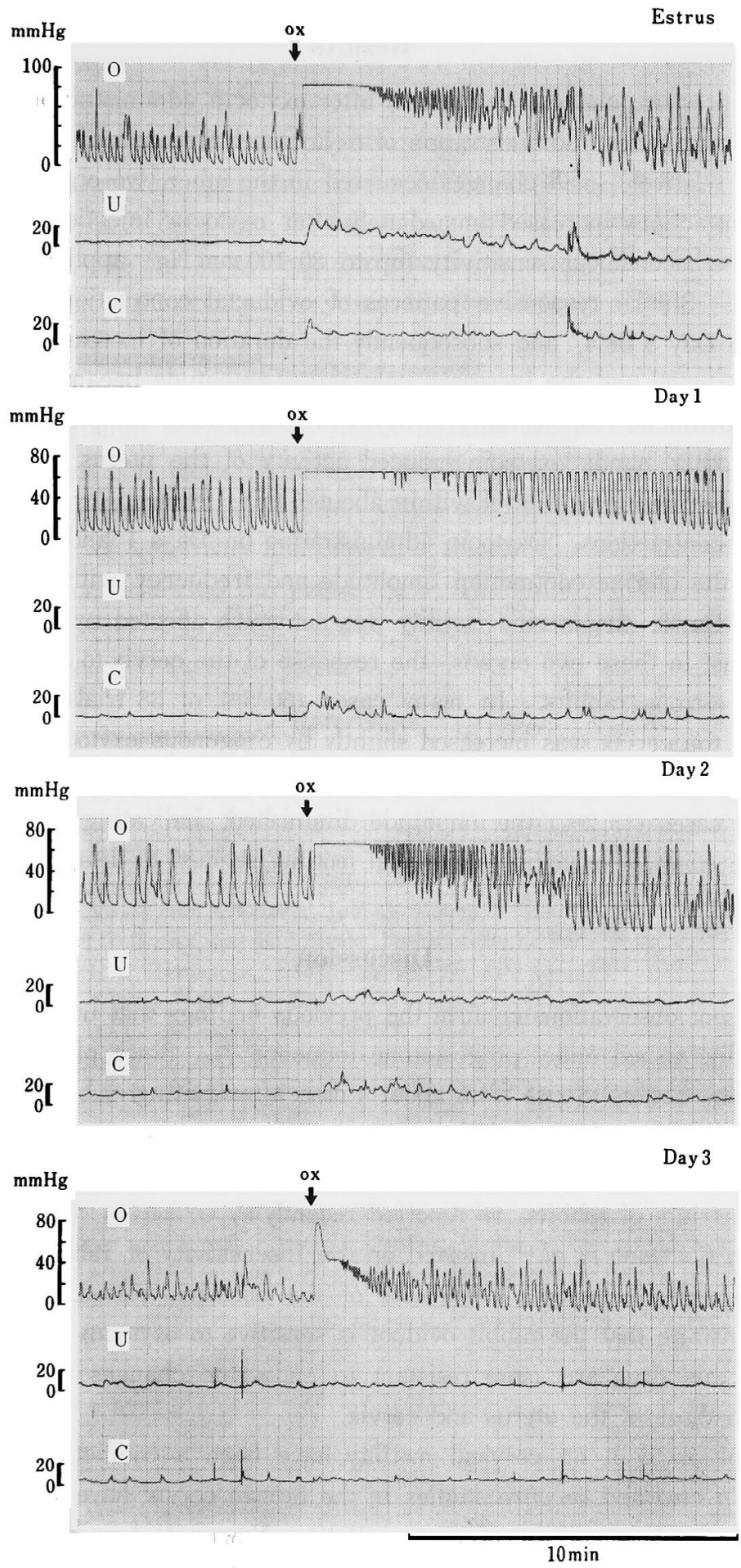

Fig. 1. Effect of oxytocin administration on contractility of the oviduct $(\mathrm{O})$, uterus (U) and cervix (C) of a rabbit before and after mating (up to Day 3). 


\section{Results}

Typical pressure changes before and after oxytocin administration are shown in Fig. 1. During estrus, administration of oxytocin elicited a marked response in the oviduct, but relatively small changes occurred in the other two organs. The tone of oviductal contractions increased immediately after oxytocin injection, the magnitude exceeding the mechanical sensitivity (up to $80-100 \mathrm{~mm} \mathrm{Hg}$ ) applied in the present investigation. Similar responsive patterns of oviductal contractions to oxytocin occurred up to Day 3 or 4 , and subsequently the duration of increased tubal tone was gradually shortened and the increased contraction amplitude became smaller. In 2 of 5 does, the oviductal responsibility to oxytocin disappeared completely on Day 7 .

On the other hand, oxytocin-induced activity of the uterus in estrous rabbits returned to the preinjection level within about $5 \mathrm{~min}$, followed by slightly increased amplitude of contractions. Oxytocin administration on Days 1 and 2 induced slight increases in the uterine contraction amplitude and frequency without a rise in the tone. After Day 2, the uterine motility was not much affected by oxytocin injection.

In contrast to these two organs, the response of the cervix to oxytocin was variable even in estrous rabbits, In many cases (60.5\% of 38 trials), the contraction amplitude in the cervix was increased slightly by exogenous oxytocin. However, in some cases $(26.3 \%)$ the cervix did not respond even if the uterus was responsive, and in other cases $(13.2 \%)$ the amplitude diminished, indicating a relaxation of the cervix. The effect of oxytocin on cervical motility seemed to disappear on and after Day 3.

\section{Discussion}

The present observations confirm the previous findings that uterine sensitivity to oxytocin is diminished under progesterone influence ${ }^{1-5)}$. Since plasma concentration of progesterone begins to rise from about 4 days after mating ${ }^{7,8)}$, our data may support the "progesterone-block" theory of $\mathrm{CSAPO}^{9,10)}$. This alteration in uterine responsiveness to oxytocin may be coincident with changes in number of oxytocin receptors in the myometrium of rabbits, as reported recently ${ }^{11}$.

Although Coutinho et al. ${ }^{12)}$ insisted on the insensitivity of rabbit oviduct to the stimulatory action of oxytocin regardless of the hormonal status, the present data clearly demonstrate that the rabbit oviduct is sensitive to oxytocin and that the tubal responses to this drug are more resistant to endocrine changes following ovulatory stimulus than those of the uterus and cervix.

Effects of oxytocin on cervical motility have been a conflicting matter in the literature. In vivo and in vitro studies in the human cervix have lacked unity concerning the stimulatory effect of oxytocin ${ }^{13-15}$. NEWTON ${ }^{16)}$ found that isolated and sliced cervix of goat did not respond in vitro to oxytocin, even in very large doses. In contrast, ADLER et al. ${ }^{17}$ reported, using a small balloon technique, that the cervices of the rabbit, cat and guinea pig do contract in response to oxytocin in most experi- 
mental cases. They pointed out, however, that there is no consistency in the cervical responsiveness to oxytocin: it elicits an increase, a decrease or no change in cervical motility.

The present results show that the effectiveness of oxytocin in the rabbit reproductive tract is organ-dependent, as mentioned by ADLER et al. ${ }^{17)}$. Since the oviduct was more sensitive to oxytocin than were the other two organs, it is possible that exogenous oxytocin may have a role on the control of oviductal egg transport, although Tsutsumi et al. ${ }^{18)}$ speculated on the inability of oxytocin to alter the rate of egg transport.

\section{Acknowledgements}

The authors gratefully acknowledge Nihon Kohden Kogyo Co., Ltd., Japan, for providing the polyurethane balloon catheters, and Teikoku-Zōki Co., Ltd., Japan, for supplying human chorionic gonadotrophin. They are also indebted to Prof. W. J. Melien, Department of Veterinary and Animal sciences, University of Massachusetts, Amherst, U.S.A., for reviewing the manuscript. The work was supported in part by a Grant-in-Aid for Co-operative Research (Project no. 536021) from the Ministry of Education, Science and Culture, Japan.

\section{References}

1) Fuchs, A. R., Fertil. Steril., 23: 915-923. 1972.

2) Fuchs, F. and A. R. Fuchs, Acta Endocrinol, 29: 615-624. 1958.

3) Fuchs, F. and F. Koch, Acta Endocrinol., 42: 403-411. 1963.

4) Schofield, B. M., J. Physiol. (Lond.), 138: 1-10. 1957.

5) Schofield, B. M., J. Physiol. (Lond.), 151: 578-590. 1960.

6) Suzuki, H., Y. Tsutsumi and K. Ogawa, Jpn. J. Zootech. Sci., 52: 382-391. 1981.

7) Challis, J.R.G., I. J. Davies and K. J. Ryan, Endocrinology, 93: 971-976, 1973.

8) Hilliard, J, and L. W. Eaton, JR., Endocrinology, 89: 522-527. 1971.

9) $\mathrm{C}_{\mathrm{SAFO}}$, A. I., Am. J. Anat., 98: 273-291. 1956.

10) Csapo, A. I., Am. J. Obstet. Gyn., 85: 359-379. 1963.

11) Nissenson, R., G. Flouret and O. Hechter, Proc. Natl. Acad. Sci. USA., 75: 2044-2048. 1978.

12) Coutrnho, E. M., C.E.R. De Martos and A.R. DA Silva, Fertil. Steril., 22: 311-317. 1971.

13) Danforth, D. M., Am. J. Obstet. Gyn., 68: 1261-1271. 1954.

14) Hilimer, K. and S.M. M. Karim, Br. J. Pharmacol., 40: 576-577. 1970.

15) Schild, H. O., R. J. FitzPatRick and W. C. W. Nixon, Lancet, 1: 250-253. 1951.

16) Newron, W.H., J. Physiol. (Lond.), 81: 277-282. 1934.

17) Adrer, J., G. H. Bell and J. A. C. Knox, J. Physiol. (Lond.), 103: 142-154. 1944.

18) Tsutsum, Y., T. Takeda, M. IdA and S. HarA, J. Fac. Agr. Hokkaido Univ., 58: 557-574. 1978. 


\title{
外因性のオキシトシンが倠家鬼生殖道の 収縮運動に及ぼす影響
}

\author{
堤 義雄・鈴木裕之 \\ 北海渞大学農学部，札幌市 060
}

\begin{abstract}
卵移動に及ぼすオキシトシンの影暗索知るために，卵 管峡部，子宮ならびに子宮頸の収縮運動に対する影響を 交配前後の家鬼を用いて追求した．オキシトシンに対す る郋管の反応性は交配前ならびに交配後 3-4 日目まで顕 著であった。.その後, 徐々㳊低下したが、5 羽の供試鬼の らち2羽で交配後 7 日目に急激度反灾性の低下がみられ
\end{abstract}

た. 子宮運動は交配後 2 日目までオキシトシンによって 影響を受けたが，その後子宮の感受性は低下した．交配 前の子宮頸の反応には一定の傾向がみられなかったが， 交配後 3 日目では全く反応しなくなった。

日畜会報, $52(12) ： 898-902,1981$ 